\title{
The Exploration of Cohesive Devices in Synopsis Writings Produced by English Study Program Students of Universitas Gadjah Mada
}

\author{
Asprilla Aqmarinal \\ ${ }^{1}$ Corresponding author, - , Yogyakarta, Indonesia; asprillaaqmarina@gmail.com
}

\begin{abstract}
Cohesive devices in a piece of writing serve to unify sentences within a text. Building upon Halliday and Hasan's (1976) Cohesion in English, this study aimed to identify and classify cohesive devices and also to discover the effects of cohesion overuse and underuse found in synopsis writings written for Book Report 1 and Book Report 2 assignment. The data were collected from 40 synopsis writings produced by the $4^{\text {th }}$ and $5^{\text {th }}$ semester students of English Study Program of Universitas Gadjah Mada. The data analysis applied a qualitative method and the data collection used purposive sampling technique. The findings showed that reiteration was the most prominently used type and followed by reference, conjunction, and collocation with the frequency 2,193 (56.94\%), 1,405 (36.48\%), 64 (2.92\%), and $252(6.54 \%)$ times respectively. Other types with low occurrences were elliptical and substitutional cohesion that occurred $3(0.078 \%)$ and $2(0.051 \%)$ times respectively. In some cases, students tended to overuse and underuse cohesive devices. In terms of cohesion overuse, in some cases, the use of reiteration leading to lexical redundancy and monotonous sentences. And in cohesion underuse, the lack of using personal reference and temporal conjunction yielding ineffective and less cohesive sentences.
\end{abstract}

Keywords: Cohesive Devices; Discourse Analysis; Synopsis Writings.

\section{Introduction}

Cohesive devices in a piece of writing serve to unify sentences within a text. Baker (1992) proposed cohesion as "the network of lexical, grammatical, and other relations which provides links among various parts of a text" (p. 180). The use of cohesive devices is important to create a good quality of writing by using appropriate words that support the text to be well-structured, coherent, and readable.

As discussed by Suningsih (2016), Rankema argued that cohesion referred to "the connections which have their manifestation in the discourse itself, and coherence refers to the connections which can be made by the reader or listener based on knowledge outside the discourse" (p. 10). In terms of readability, Rezaee and Norouzi (2011) proved that cohesive markers support the legibility of a text. In their study, they stated that grammatical cohesive 
markers helped students to show the intended meaning and to serve logical connectivity in Reading Section on TOEFL tests (p. 1010).

Halliday and Hasan (1976) provided a classification of English cohesion in their Cohesion in English. They argued cohesion is a semantic concept that discusses the relation of meaning within a text (p. 4). They defined cohesion as an intersentential semantic relation, not as intrasentential or structural relation within a sentence. With regards to that, they doubted that, in principle, cohesive relations do not have any relation with sentence boundaries (p. 8).

Students majoring in English Study Program at Universitas Gadjah Mada are at some point assigned to write a synopsis of the literary works they read. In general, cohesion in a synopsis is to present a chronological order of events by using conjunctive relation. In addition, cohesion also acts to refer back to characters, things, or events that have been stated previously by using referential type. Nonetheless, there are some problems encountered by students in using cohesion. It can be seen from the data used in this study which revealed that there are several cases on overuses and underuses of cohesion found in the students' writings.

Along these lines, this study attempts to identify the use of cohesive devices in the writing of synopses for Book Report produced by the $4^{\text {th }}$ and $5^{\text {th }}$ semester students of English Study Program of UGM. Further, it also discusses the cohesion overuse and underuse leading the synopses are at some points incomprehensible, ineffective, and less cohesive.

\subsection{Literature Review}

Cohesive devices inarguably play an essential role in a piece of writing. According to Zemach and Rumisek (2005) "cohesive devices are words and phrases that connect sentences and paragraphs, creating a smooth flow of ideas" (p. 82). Recent studies as conducted by Suningsih (2016), Abdurrahman (2013), Widyastuti (2014), and Azzouz (2009) have revealed that the use of cohesive devices in essays written by learners English of a second language leads the writings to be cohesive. The trend among the studies has shown that reference, conjunction, and lexical cohesion are frequently used compared to substitution and ellipsis.

Even so, there are some problems encountered by students in using cohesive devices as seen in studies conducted by Al-Shekali (2011), Guna and Ngadiman (2015), and Heino (2010). They revealed that there are cohesion overuse and underuse in their students' essays. The cohesion overuse is mostly produced by the use of unnecessary pronouns and conjunction and students' tendency to use repetition of lexical items yielding redundancy. In terms of cohesion underuse, students tended to omit particular cohesive devices that are supposedly used as argued by Ong (2011). She stated that cohesion overuse occurs when "a particular cohesive device is expected in the text but is not there" (p. 49).

Eliminating mistakes in language learning, including writing, seems difficult to do. However, there are some suggestions to lessen some problems in writing. Following the cause of the problems, Tirtasari (2015) found that the problems happened because cohesion is less frequently taught in class. Therefore, she suggested holding a bigger proportion of cohesion explanation in grammar class and more practice in writing class (p. 67-68). In addition, Nugraheni in her journal suggested that teachers could ask students to do peer editing to enrich students' knowledge about cohesion as well as their writing skill (p. 61). 


\subsection{Theoretical Framework}

\subsubsection{Halliday and Hasan's Cohesion in English 1976}

As having explained previously, cohesion is studied as a semantic concept that discusses the relation of meaning within a text (Halliday \& Hasan, 1976, p. 4). Cohesion is demonstrated partially through the grammar and the vocabulary (p. 5). Grammatical cohesion consists of reference, substitution, ellipsis, and conjunction, while lexical cohesion includes reiteration and collocation.

\subsubsection{Reference}

Reference deals with the semantic relation of some particular subjects within the text. Halliday and Hasan (1976) defined reference as "the specific nature of the information that is signaled for retrieval" (p. 31). There are three types of reference namely personal, demonstrative, and comparative reference. Personal reference functions to refer PERSON, while demonstrative reference points particular subjects on a level of PROXIMITY, and comparative reference serves to compare particular subjects by means of IDENTITY or SIMILARITY (p. 37).

\subsubsection{Substitution}

"Substitution is a relation between linguistic items, such as words or phrases ... substitution is a relation on the lexicogrammatical level, and the level of grammar and vocabulary, or linguistic "form"' (Halliday \& Hasan, 1976, p. 89). Based on the explanation, substitution is a cohesive part that emphasizes on wording (grammatically) rather than meaning (semantically). Therefore, the type of substitution consists of nominal substitution, verbal substitution, and clausal substitution. In nominal substitution, the cohesive devices substitute the item of the nominal group with one/ones and same. While in verbal substitution, the cohesive markers substitutes a verb in the preceding text with $d o$, or else such as does, doing, did, done depend on the doer and the situation. In the level of a clause, so and not are used as a to substitutes some particular items.

\subsubsection{Ellipsis}

"Ellipsis is defined as the omission of an item or briefly explained as substitution by zero (Halliday \& Hasan, 1976, p. 88-89)". As part of substitution, ellipsis has also three types like substitution, namely nominal ellipsis, verbal ellipsis, and clausal ellipsis. In nominal ellipsis, the Head part in a sentence is omitted. In this type, there are three elements as its role as Head namely deictic (determiners), numerative (numerals), epithets (adjectives), and classifiers (nouns). While at verbal level, the principal system of ellipsis is finiteness, polarity (positive or negative), voice (active or passive), and tense (past, present, or future). Verbal ellipsis is divided into two sub-types, namely lexical ellipsis and operator ellipsis. And the last, in the level of clause, there are four sub-types which are propositional, modal, general, and zero ellipsis.

\subsubsection{Conjunction}

Conjunction is the fourth type of cohesion proposed by Halliday and Hasan (1976). They state "conjunction elements are cohesive not in themselves but indirectly, by virtue of their specific meanings; they are not primarily devices for reaching out into the preceding (or following) text, but they express certain meanings which presuppose the presence of other 
components in the discourse" (p. 226). Further, Baker (1992) explains "conjunction involves the use of formal markers to relate sentences, clauses, and paragraphs to each other" (p. 190).

Halliday and Hasan (1976) divided conjunction into four types namely additive, adversative, causal, and temporal. They differed these types in terms of ideational meaning (EXTERNAL) and interpersonal meaning (INTERNAL). "Internal relations are mostly employed in the global organization of text that operates in tenor oriented context, whereas external relations appear in field-oriented context (e.g. procedural texts and recounts)" (Halliday \& Matthiessen 2014, p. 612).

\subsubsection{Lexical Cohesion}

Lexical cohesion is devided into two categories, namely reiteration and collocation. "Reiteration is a form of lexical cohesion which involves the repetition of lexical item" (Halliday \& Hasan, 1976, p. 278). This type consists of (1) repetition of the same word, (2) synonym (or near-synonym), (3) superordinate, and (4) general words. Reiteration is usually used to avoid the misconception or to give a strong impresssion to the topic discussed by the use of various words as categorized in the preceding sentence.

Collocation is explained as a cohesion that is achieved through the association of lexical items that regularly co-occur. This type includes

“(1) mutually exclusive categories, (2) particular type of oppositeness include complementary, antonymy, and converseness, (3) pairs of words obtained from the same ordered series, (4) any pairs derived from unordered lexical sets, (5) words that related as part to whole or as part to part, (6) member of the superordinate expression" (Halliday and Hasan, 1976, p. 284-285).

Collocation is usually used to build the atmosphere to the topic discussed by the exploration of variety of words which are related in meaning.

\subsubsection{Cohesion Overuse and Underuse}

Writing, especially academic writing, should be written in a good manner, including to be cohesive. To write a well-structured text, one needs knowledge on how to use cohesion properly and adequately. Hence, there will be no problems in his/her writing such as cohesion overuse and underuse.

According to Fox et al. (2003), overuse is defined as "to use something too much, especially so that it is not effective anymore or it is damaged" (p. 1179). While, underuse is termed as something is not used as much as it could be, less of an action or quality than is correct, needed, or desired (p. 1804). From the two definitions, cohesion overuse can be characterised as the use of excessive cohesion causing ineffectiveness, while cohesion underuse can be expressed as the lack of using cohesion seen from its correctness, need, and desire.

Further, Ong (2011) listed the following characteristics about cohesive errors which are also used to evaluate cohesion overuse and underuse in the synopsis writings:

"a. Unnecessary addition occurs when a particular cohesive device is used unnecessarily or redundantly in the text.

b. Omission of cohesion device occurs when a particular cohesive device is expected in the text but is not there. 
c. Redundant repetition of cohesive device is used to describe the cohesive devices which are used more than once in the text but either some or all of the use can be replaced by other words." (p. 49)

\subsubsection{Book Report and Synopsis}

Book Report is an individual reading project of English and American classic literary works assigned for the $4^{\text {th }}$ and $5^{\text {th }}$ semester students of English Study Program of Universitas Gadjah Mada under the supervision of their corresponding academic supervisor. It enables students to explore their understanding or interpretation of the works through the analysis of papers and deliver their statements in an oral report. The structures of Book Report consist of (1) a brief description of the book which includes the subject of the study, the main characters, plot or synopsis, and turning points and (2) in-depth discussion of some issues such as themes, topics, aspects, motifs, symbols, and moral values.

Synopsis is widely understood as a summary of major events of a story to provide general information to reader. In Book Report, a synopsis is presented to give a general knowledge about the story discussed. Cohesive devices in a synopsis writing function to serve relations of meanings by signaling back some certain subjects that has been stated previously by the use of reference. The second is by creating effective sentences by the use of substitution and ellipsis. The third one is by connecting the sequence of events by the use of conjunction. And lastly is by avoiding misinterpretation discussed by the use of variety of vocabularies under the classification of lexical cohesion.

\section{Method}

This study applied a descriptive qualitative method. Bogdan and Taylor in Moleong (2005) stated that a qualitative method offers descriptive data in the forms of written or spoken information and noticeable behaviors (p. 5). In addition, qualitative research provides new ideas and criticisms, and it supports enhancement and improvement to the learning process (Arikunto, 2014, p. 10).

\subsection{Respondents}

The respondents were four students of the 4th and 5th semester students of English Study Program of Universitas Gadjah Mada. Each student produced 10 synopses in which the five synopses were written in their $4^{\text {th }}$ semester and the other five were written on their $5^{\text {th }}$. The synopses were used as the data sources of this study.

\subsection{Procedures}

The method of data collection is using purposive sampling technique in which 40 synopses were chosen based on the cohesion overuse and underuse found in their synopsis writings. The first step of the data collection was reading all of the synopses. The second was rereading the synopses and also classifying the cohesive devices and giving notes to the cohesion overuse and underuse. The next step was calculating the cohesion used in each synopsis. And the last was calculating the cohesive devices based on each the type in order to see the trend of using cohesion. 


\subsection{Data Analysis}

After the data were collected, the first step of analysis was classifying the data into English cohesion classification as proposed by Halliday and Hasan (1976) namely: reference, substitution, ellipsis, conjunction, and lexical cohesion. The next step was calculating the classified data to determine which type was the most frequently used and also to see the trend toward its use. Subsequently, the findings are discussed based on each type of cohesion and cohesion overuse and underuse found in the Book Report 1 and Book Report 2.

\section{Finding and Discussion}

\subsection{Research Questions}

Based on the background of choosing the subject, there are two research questions that can be formulated, namely:

1. What cohesive devices are used in the synopsis writings?

2. What are the effects of cohesion overuse and underuse in the synopsis writings?

\subsection{The Use of Cohesive Devices in Synopsis Writings}

The frequency of cohesive devices occurrences is presented in the pie chart below along with the analysis description.

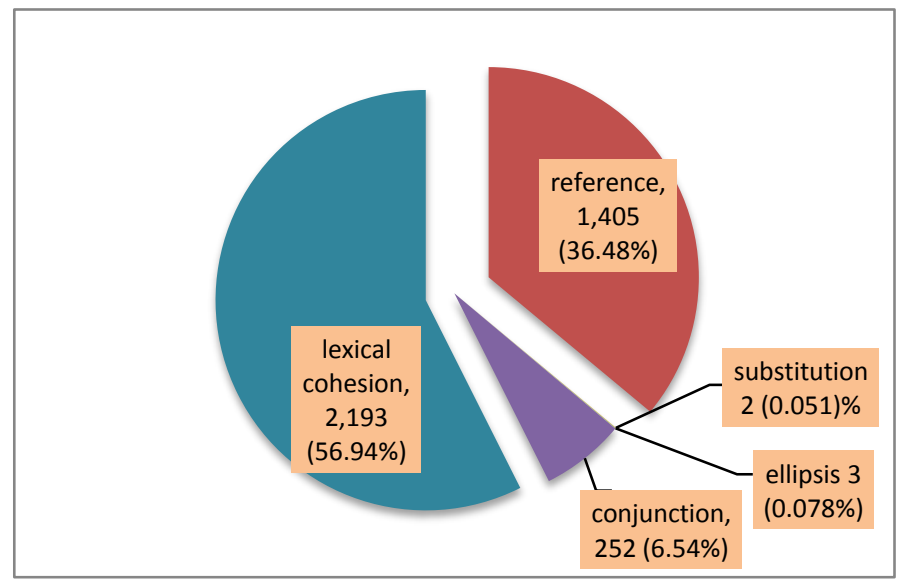

Figure 1. The Use of Cohesive Devices in Synopsis Writings

The general result shows lexical cohesion stands on top position with the number of occurrences is $2,193(56.94 \%)$. It includes the repetition of lexical for characters' names, places, and events for multiple times and also the use of collocation. Even though it stands on the highest number of occurrences, there are some lexical redundancies. It can be seen from the use of repeated names to refer back to some characters' names. It is supposed to use personal pronouns instead of repetiting with the same lexical. The next largest number of occurrences is referential cohesion with the number of occurrences is $1,405(36.48 \%)$. This type is commonly used to substitute characters' names, places, and events into personal pronouns, possessive determiners, possessive pronouns, and demonstrative reference. However, the use of this type is deficient due to the frequent use of repetition sub-type. The third-largest amount of occurrences is the use of conjunctive cohesion that is 252 (6.54\%). The most frequently use of conjunction type is a temporal sub-type which functions to relate one event to another. However, the use of temporal type is considered deficient. It can be 
seen from some monotonous sentences and unclear chronological orders of the story. And the last result is the use of substitution and elliptical cohesion that only contribute little to the synopses. It is because these two types are deemed not significant to the writings.

\subsubsection{Reference}

Reference deals with the semantic relation of some particular subjects within the text. The use of reference in the synopses is understood as an attempt to replace characters' names and the setting of places into personal pronouns, possessive determiners, and possessive pronouns. The following table shows the frequency of referential cohesion occurrences.

Table 1. The Frequency of Referential Cohesion Occurrences

\begin{tabular}{|l|l|l|l|}
\hline NO & Types of Referential Cohesion & $\begin{array}{l}\text { Number of } \\
\text { Frequency }\end{array}$ & Percentage \\
\hline 1 & Personal Reference & 807 & $57.40 \%$ \\
\hline 2 & Demonstrative Reference & 584 & $41.60 \%$ \\
\hline 3 & Comparative Reference & 14 & $1 \%$ \\
\hline \multicolumn{2}{|l}{ TOTAL } & 1,405 & $100 \%$ \\
\hline
\end{tabular}

As seen in the table above, personal reference stands on the top position and followed by demonstrative and comparative reference. The highest number on personal reference is because the use of pronoun to signal back to the characters' names. Here are the following discussions of reference type.

(1) The story started when the much younger Nick moved to West Egg, Long Island, from the Midwest. He visited his cousin, Daisy, on the East Egg and found out that Daisy's husband, Tom, was having an affair with Myrtle Wilson. (S 31)

The example above presents the use of masculine sub-sub class of personal reference that is he and his. Both words refer back to Nick. He functions as a Head while his functions as a modifier to show possession.

(2) The ghost then shows Scrooge one Christmas celebrated by Belle and her family in which her husband describes Scrooge as a lonely person in the world. Having enough of it, Scrooge then forces the ghost to leave him by covering the ghost with its cap ... . (S 4)

Besides functioning to point to non-human animate objects such as a variety of animals, it can also refer back to inanimate things such as stuff, idea, situation, fact, and the like. As in the example, personal reference it refers back to the situation or Scrooge's past time memory that he could not bear to see (in the preceding sentence). In addition, it functions as a Head.

(3) Utterson reads Lanyon's letter and figures out that Lanyon saw Hyde turned into Jekyll after drinking a serum. ... . When Jekyll suddenly transformed to Hyde outdoor, he asked Lanyon to help get the serum, and that was when Lanyon saw him changed in terror. (S 2)

The definite article the helps to signal back the word serum in the previous sentence. The functions as a modifier. It is clear that the use of the helps to present the definite serum that is being discussed. Another example below presents the use of selective system of demonstrative reference. 
(4) Later on another night, Hyde is seen beating a public figure named Sir Carew and the police finds a broken cane in Hyde's mansion that Utterson identifies as his gift to Jekyll. When asked about this, Jekyll shows an apology note he received from Hyde. (S 2)

Besides functioning as a modifier, the article of 'that', 'this, 'those', 'these' also function as a Head. The article this explains the situation (in the previous sentence) without rewriting the whole clause. It is obvious since this is already substituted the clause or the whole situation of Hyde experienced. "A demonstrative functioning as Head is more like a personal pronoun since, in fact, both it and the are reduced forms of that" (Halliday \& Hasan, 1976, p. 8).

Soon later, the animals receive the news from Squealer that Boxer has died in the hospital, while in fact Napoleon has sold him to for meat, and uses the money to buy whisky. From then, the pigs begin to act a lot like humans by wearing shirts, walking with two legs, and even handling whips. (S 10)

Another example explains the selective system of demonstrative reference in a form of time. The article then signals back to the period when Boxer dead in the previous sentence. Besides explaining in referential cohesion, then is also used in conjunction class which explains its relation to temporal relations. However, the difference between the two is quite understandable. The cohesion then in demonstrative reference refers back to a location of a process in time. While in temporal conjunction then is a transitional signal which explains the sequence of time events.

\subsubsection{Substitution}

The frequency number of substitution in the synopses is two occurrences. Clausal substitution is the only type found in the synopsis writings. Here are the following discussions.

(6) As they got in a cab, Brett says that she and Jake would have had a good time together. Too which Jake replies, "Yes, isn't it pretty to think so?" (S 14)

(7) Then Pip went to London to learn how to become a gentleman. His life was perfect with a sealed future. Or so he thought. (S 36)

The two sentences contain substitutional relation so that refers back to the clauses in the preceding sentences. To write a cohesive writing, there is no need to repeat subjects that have gone before by using the same lexical, phrase, clauses or even a whole sentence. The presence of one, ones, same, do, so and not in substitution type helps to refer back something in a brief arrangement

\subsubsection{Ellipsis}

Ellipsis is defined as "the omission of an item" (Halliday \& Hasan, 1976, p. 187) or "simply as substitution by zero" (p. 142). In the synopsis writings, nominal ellipsis sub-type is the only type found.

(8) He spends months reparing his boat and there he meets the Brickmaker who tries to get information from him ... . Done repairing $\emptyset$, Marlow proceeds his journey. (S 5)

(9) He found a massive pearl. The biggest the village has ever seen. (S 12) 
(10) Lennie told her that he loves petting soft things, and she offered him to feel her hair. When he grabbed $\emptyset$ too tightly, she cried out. Lennie, afraid and in an attempt to silence her, accidentally broke her neck. (S 16)

The three instances omit the words the boat as in (30), pearl as in (31) and her hair as in (32). Using elliptical cohesion is a nice attempt to avoid repetition that creates an ineffective sentence. However, the use of elliptical cohesion in any writings, based on the previous studies as written in the literature review, is considered rare because in most cases, the omission of certain subjects is worried to lead the text to be incomprehensible and ambiguous.

\subsubsection{Conjunction}

Conjunction is the fourth type of English cohesion in terms of grammatical cohesion. Different from other types of cohesion that functions to refer back to particular subjects in the preceding sentence (or following), conjunction type provides "formal markers" (Baker, 1992, p. 190) to connect one sentence to another in terms of additive, adversative, causal, and temporal relations. For this reason, conjunctive cohesion is also called as 'discourse markers'. The following table is the number frequency of conjunction used in the synopses.

Table 2. The Frequency of Conjunctive Cohesion Occurrences

\begin{tabular}{|l|l|l|l|}
\hline NO & Types of Conjunctive Cohesion & $\begin{array}{l}\text { Number } \\
\text { Frequency }\end{array}$ & of \\
\hline 1 & Additive Conjunction & 24 & $9.52 \%$ \\
\hline 2 & Adversative Conjunction & 17 & $6.74 \%$ \\
\hline 3 & Causal Conjunction & 5 & $2 \%$ \\
\hline 4 & Temporal Conjunction & 206 & $81.74 \%$ \\
\hline TOTAL & 252 & $100 \%$ \\
\hline
\end{tabular}

The table shows that temporal conjunction stands on the top position followed by additive, adversative, and clausal conjunction. The highest number of temporal conjunction is due to many sentences that require strong and logical connection. Here are the following discussion of conjunctive cohesion.

(11) On Christmas Eve, he made his clerk, Bob Cratchit, work in the cold. Also, he refused an invitation to his nephew's Christmas party and would not give any money to the charity collectors. (S 37)

Additive conjunction that is used in the writings is called simple additive relations also. It is clear enough that also tries to connect Cratchit's attitudes on Christmas day between the two sentences. The relation is classified as EXTERNAL since it associates two different events, namely he made his clerk, Bob Cratchit work in the cold and he refused an invitation to his nephew's Christmas party.

(12) He then concluded that Daisy is in fact a disreputable woman and would not bother about her anymore. However he is still concerned for her health and urges Giovanelli to take her home. (S 11)

The cohesion however explains a contrast situation done by Giovanelli. He said that, at first he would not to bother Daisy anymore, however in the subsequent sentence, he actually still paid attention to her health. A further discussion of the example can be explained in a 
reversal form as follow "Although he (Winterbourne) would not bother about her (Daisy) anymore, he is still concerned for her health".

Daisy, however, refuses to listen to her and Winterbourne.... . Winterbourne called her hotel and Mrs. Miller, Daisy's mother, told him that Daisy wanted him to know she actually cared about his thought on her. (S 11)

The second sentence presents Daisy's contradict attitude towards Winterbourne's concern as written in the previous sentence. At first, she denied all of the advice addressed to her. Yet, in the final, she said that she actually cared about his thought. The use of actually shows a contrast attitude a contradict behavior that leads to Winterbourne's confusion about Daisy's true personality.

(14) Three months after Old Major dies, Mr. Jones, Manor Farm's owner, gets drunk and forgets to feed the animals. Accordingly they riot. (35)

The second sentence contains causal relation accordingly that explains the result of $\mathrm{Mr}$. Jones' forgetfulness to feed the animal. The relation is counted as EXTERNAL sense since it tells about the ideational meaning that states the reason(s) as the effect of the incidents from the earlier sentence. The sentences can be stated in a reversal form that is Because $M r$. Jones, Manor Farm's owner, gets drunk and forgets to feed the animals, they riot.

(15) Scrooge is visited by Fred, his nephew, who asks him to celebrate Christmas together and gets rejected. Quickly after that, two gentlemen come in to ask for donation from Scrooge and are rejected by Scrooge who does not celebrate Christmas. (S 3)

The transitional signals quickly after that shows subsequent events after Scrooge is visited by Fred. It is classified in temporal conjunction since "they are paralleled by the sequence of the sentence themselves: the second sentence refers to a later event" (Halliday \& Hasan, 1976, p. 262). In terms of the relation of meaning, both are grouped as EXTERNAL relations since the devices connect two different facts.

(16) Biff tries to tell Willy about his situation but Willy seemed to refuse hearing and they went into an argument. ... . Biff says goodbye to Willy but the two soon broke into argument again, which in the end leaves Biff in tears. (S 15)

The sentence presents complex temporal relations of repetitiveness. The repetitive relation is showed by the word again that explains the recurrence of the argument activity done by Biff and Willy. In the full synopsis, they often had arguments about a proper life that should be achieved by Biff. The sentence shows temporal relation that is the recurrence of certain events that connect one another.

\subsubsection{Lexical Cohesion}

The use of same lexical to highlight characters' names, places, and events as a part of lexical cohesion is frequently found in the students' writings. There are two sub-classes of lexical cohesion namely reiteration and collocation. The following table shows the frequency of lexical cohesion occurrences. 
Table 3. The Frequency of Lexical Cohesion Occurrences

\begin{tabular}{|l|l|l|l|}
\hline NO & Types of Conjunctive Cohesion & $\begin{array}{l}\text { Number } \\
\text { Frequency }\end{array}$ & Percentage \\
\hline 1 & Reiteration & 2,000 & $91.2 \%$ \\
\hline 2 & Synonymy & 53 & $2.41 \%$ \\
\hline 3 & Superordinate & 6 & $0.27 \%$ \\
\hline 4 & General Words & 70 & $3.2 \%$ \\
\hline 5 & Collocation & 64 & $2.92 \%$ \\
\hline TOTAL & 2,193 & $100 \%$ \\
\hline
\end{tabular}

The table shows that the most frequently lexical cohesion used for the synopsis writings is reiteraion and followed by general words, collocation, synonymy, and superordinate. Here are the following discussions of lexical cohesion.

(17) The story opens on a young boy, Jimmie Johnson of the Rum Alley children, who is brawling with children from Devil's Row (a nearby area in the Bowery, in Manhattan). Jimmie fights with Blue Billie of Devil's Row, but their altercation is interrupted by the arrival of Pete, an older friend of Jimmie's. (S 31)

The words Jimmie and Devil's Row are repeated to refer back to Jimmie as the character involved in the story as well as Devil's Row as the setting of place. The use of repetition is understood as an attempt to highlight the main points discussed.

Right as he was about to strike, Coyotito cried and wakes the sleeping trackers. One of the trackers then shoots at the crying sound and Kino leapt to kill all three of them. (S 12)

As seen in the instance above, the word crying refers back to cried even though it does not apply the same morphological shape. Crying is an adjective and a modifier to the word sound while cried is a verb. "In order for a lexical item to be recognized as repeated, it need not be in the same morphological shape" (Halliday \& Matthiessen, 2014, p. 644).

(19) The town people are talking about her for her less-mannered conducts, including the American people that are in the town, especially Mrs. Walker, a friend of Winterbourne who happens to have been seen Daisy's family. When she is advised to mind her behavior that has made a bad term ... . ( $\mathrm{S}$ 8)

Similar to the previous instance, the use of synonymy is an effort to avoid using the same lexical to refer back to an identical subject. As seen in the example above, the word behavior is a replacement of conducts. These two words have the same meaning, namely the way of person behaves in a particular situation or place.

(20) The narrator begins the story when he visits Starkfield, Massachusetts during winter time for business inquiries and happened to meet Ethan Frome, a man with limb and scars. ... . He has been living there ever since, with his injuries resulting from an accident he had long ago. (S 1)

To make a concise explanation, the word injuries is chosen as a replacement of limb and scars. Since injuries is a more general class of limb and scars, limb and scars is subordinate 
of injury. "Hyponymy is common where a passage of text is being developed by means of elaboration" (Halliday \& Matthiessen, 2014, p. 647).

(21) The narrator begins the story when he visits Starkfield, Massachusetts during winter time for business inquiries and happened to meet Ethan Frome, a man with limb and scars. Growing in curiosity, he asked townsfolk about that person but receives little information. (S 1)

The word person or human noun replaces a character named Ethan Frome. This replacement is an attempt to avoid redundancy and a monotonous tone. In general, the use of lexical cohesion is commonly accompanied by a modifier. In the example, a modifier that signals Ethan Frome as the character discussed.

Currently, they live under the tyranny of the ranch owner, Mr. Jones. The old major came to the conclusion that one day the revolt would take place by animals against human. ... . They could farm by getting more abundant crops than before. They work together to take harvest without anyone stealing it. (S 39)

The synopsis above presents collocational words of farming such as ranch, animals, farm, crops, and harvest. The use of lexical collocation in the example is an effort to build a good setting for the reader. As Hasan and Halliday (1976) explained, "a particular collocational environment that has been built up in the course of the creation of the text and that will provide the context within which the item will be incarnated in this particular occasion" (p. 289). The collocational environment here means a set of lexemes grouped semantically that share similar concept or related in meaning.

\subsection{Cohesion Overuse and Underuse}

Writing cohesively means that the text should employ cohesive devices appropriately and adequately. Yet, unfortunately, most students find these requirements difficult to fulfill. The causes of cohesion overuse and underuse are explained in a table below.

Table 4. The Cohesion Overuse and Underuse

\begin{tabular}{|l|l|l|}
\hline $\begin{array}{l}\text { Cohesion } \\
\text { Type }\end{array}$ & Cohesion Overuses & Cohesion Underuses \\
\hline Reference & $\begin{array}{l}\text { The use of unnecessary pronouns } \\
\text { that lead the text incomprehensible } \\
\text { and ineffective. }\end{array}$ & $\begin{array}{l}\text { The lack of exploration using } \\
\text { pronouns to substitute names of } \\
\text { characters. }\end{array}$ \\
\hline Ellipsis & - & $\begin{array}{l}\text { The overuse of repetition causing } \\
\text { ineffective sentence. }\end{array}$ \\
\hline Conjunction & $\begin{array}{l}\text { The use of unnecessary additive } \\
\text { conjunction also. }\end{array}$ & $\begin{array}{l}\text { The lack of exploration using } \\
\text { temporal conjunction that cause } \\
\text { weak connection in some sequence } \\
\text { of events. }\end{array}$ \\
\hline $\begin{array}{l}\text { Lexical } \\
\text { cohesion }\end{array}$ & $\begin{array}{l}\text { The use of repetition to signal back } \\
\text { to the characters names causing } \\
\text { redundancy. }\end{array}$ & - \\
\hline
\end{tabular}




\subsubsection{Reference Overuse and Underuse}

Reference overuse is examined from the use of unnecessary pronouns that lead the text incomprehensible and ineffective. And reference underuse is analysed through the lack of using pronoun to substitute characters' names.

(23) There he meets the General Manager who tells him that they are more concerned with Mr. Kurtz who is now very ill in his station. Marlow becomes irritated with this Kurtz. (S 5)

The sentence above contains unnecessary definite article this. According to Ong (2011, p. 49), "unnecessary addition (cohesion) occurs when a particular cohesive device is used unnecessarily". The article this functions to refer back to which particular subject that is discussed, however, the use of this in the sentence is counted not needed since the following subject is a character name. It is unfamiliar when referring back to a character name, there is a requirement to use any kind of articles. Possibly, the author aims to emphasize Marlow's annoyance towards Kurtz. But still, since there is no other Kurtz besides Kurtz that is referred to, there is no need to use the article this.

(24) Dr. Jekyll back to be social and spend lots of his time with his friends. However, days after the dinner in Dr. Jekyll place, Dr. Jekyll refused to see anyone. (S 38)

The sentence contains lexical repetition namely Dr. Jekyll that lead to redundancy and monotonous writing. Besides, the overuse creates in explaining possession. In grammar, it is supposed to be written Dr. Jekyll's place. However, to create an effective sentence, it is supposed to be written as his place. Therefore, the sentence is supposed to be written as follows "Dr. Jekyll back to be social and spend lots of his time with his friends. However, days after the dinner in his place, he refused to see anyone".

\subsubsection{Ellipsis Underuse}

Elliptical cohesion is considered rarely chosen in writing since it is hardly known by writer. Moreover, it is worried that the omission of some words creates loss of emphasis on the main subject discussed. For this reason, there are not many sentences that underuse the elliptical cohesion. It is only found in the synopsis below.

(25) They are collecting donation for the homeless and poor. But, Scrooge refuses to give donation. (S 30)

As seen in the example above, since in the first sentence the word donation has already been written, it is better to omit the word donation in the subsequent sentence to make a more effective and concise sentence. Based on the definition by Fox et al. (2003), overuse is defined as "to use something too much, especially so that it is not effective anymore or it is damaged" (p. 1179). Moreover, the omission of the word will not create an incomprehensible content and the sentence will be still understandable.

\subsubsection{Conjunction Overuse and Underuse}

The overuse of conjunction creates illogical relation to the previous sentence. Besides, it leads the reader to be confused while reading. Fortunately, the excessiveness of conjunctive cohesion is only found in the sentence below. 
When he walks in the late-night to stroll past the Colosseum, he's startled saw Daisy and Giovanelli doing as lovebirds do. He also worried she'll get a Roman fever. (S 32)

The use of also is considered not needed because it does not link or add anything to the previous sentence. According to the previous studies about conjunction overuse, the problem is produced by the use of conjunction that does not serve cohesive effect regard to the earlier sentence. The second sentence is more explain on the cause of Winterbourne's reason to worry about Daisy because she is in the Colosseum. Therefore, it is improper if the sentence uses also.

One of the functions of a synopsis is to present a brief chronological order of major events to the reader. Using conjunctive relations as transitional signals help the reader to understand the sequence of events well. However, some underuses of conjunctive relations lead the synopsis to be less cohesive as found in the example below.

(27) Mrs. Costello, Winterbourne's aunt, disapproves of him and Daisy spending time and refuses to meet her. $\varnothing$ Winterbourne still spends time with Daisy and accompanied her to Chillon Castle unchaperoned. (S 11)

The sentence underuses the adversative conjunction however. The adversative conjunction intends to present contradiction between Mrs. Costello's expectation and Winterbourne's action to set apart himself from Daisy. Further, the cohesion also helps to show Winterbourne's refusal towards Mrs. Costello's advise.

\subsubsection{Lexical Cohesion Overuse}

The overuse of lexical cohesion is examined by the overuse of reiteration. Reiteration or repetition is a good way to emphasize certain subjects discussed, but it should maintain the sentence's effectiveness. The problems between reference and lexical cohesion are overlapping. In other words, the overuse of lexical cohesion can also be analyzed as the underuse of reference. Here are the discussion.

(28) There, he learns to obey men holding club. One day, Buck is sold to men named Francois and Perrault, mail carriers of the government. Buck meets another dog, Curly, who is attacked and killed by a pack of huskies soon after they arrive in the camp. Watching this, Buck realizes that ... . (S 7)

The sentence contains redundancy of the subject Buck. In the first sentence, it has used the pronoun he to replace Buck correspond to the earlier sentence. However, in the subsequent sentences, it repeats the character name Buck that causes redundancy and monotonous sentences. Based on the previous studies, cohesion underuse can be avoided by the use of various vocabularies comes from reference, ellipsis, substitution, synonyms, antonyms, hyponyms, and general words. However, for this case, the use of personal reference can resolve the problem.

To use reiteration or repetition in the right proportion, the management must be balanced. Repetition is acceptable to use when it functions to highlight some primary words and to give a strong impression to the reader's mind about the topic discussed. But, it supposed not to create redundancy. In addition, the use of repetition is also important to avoid unclarity and ambiguous towards the presence of another subject(s) or also be called as antecedent. 


\section{Conclusion}

Deriving from the discussion on cohesive devices used in the synopsis writings, the finding signifies that the most frequently used device is reiteration followed by reference, conjunction, collocation, ellipsis, and substitution. Another finding shows that there are 107 overuses and 153 underuses of cohesion in the students' writings. The overuses emerge from the use of unnecessary words and several repetitions yielding lexical redundancy. In terms of the underuse case, there are many less connected sentences that require more explanation through the use of cohesion, especially temporal conjunction.

Drawing on the conclusions presented above, there are two interesting suggestions for future research. The first is the research will have the potential to raise learners' awareness of cohesion overuse and underuse, thus the problems could be lessen or omitted. And the second is the research is possible to relate the $\mathrm{L}_{1}$ interference to the cause of cohesion overuse and underuse. The findings are certainly will support enhancement and improvement to the learning process.

\section{Acknowledgments}

I would like to thank Dr. Aris Munandar, M. Hum as my paper consultant who had assisted and guided me while conducting and finishing my research. I sincerely gratitude him for his great supports and advices.

\section{References}

Abdurrahman, N. H. (2013). Grammatical cohesion analysis of students' thesis writing. Jurnal Pendidikan dan Pembelajaran Khatulistiwa, 2(11). Retrieved from http://jurnal.untan.ac.id/index.php.jpdpb/article/view/3962/3954

Al-Shekaili, D. A. (2011). Cohesive features in persuasive (argumentative and nonargumentative) writing produced by Omani undergraduates (unpublished Master's thesis). $\quad$ Retrieved

from https://www.awej.org/images/Theseanddissertation/DalalAbdullahAlShekaili/dalalalsh ekailifullthesis.pdf

Arikunto, S. (2014). Prosedur penelitian: Suatu pendekatan praktik (15 $5^{\text {th }}$ ed.). Jakarta, Indonesia: Rineka Cipta.

Azzouz, B. (2009). A discourse analysis on grammatical cohesion in student's writing (Thesis, University of Mentouri Constantine, 2009). Retrieved from http://archives.umc.edu.dz/bitstream/handle/123456789/11397/AZZ1086.pdf?sequence $\underline{=1}$

Baker, M. (1992). In other words: A course book on translation. Abingdon, England: Routledge.

Faradhibah, R. N., \& Nur, A. N. (2017). Analyzing students' difficulties in maintaining their coherence and cohesion in writing process. ETERNAL (English, Teaching, Learning and Research Journal), 3(2), 183-194. doi:https://doi.org/10.24252/Eternal.V32.2017.A7

Fox, C., Manning, E., Murphy, M., Urbom, R., Marwick, K. C. (2003). Practice. In Longman dictionary of contamporary English. London, England: Harlow : Longman. 
Guna, S., \& Ngadiman, A. (2015). The cohesive devices used in the cause and effect essay written by the English Department students of STKIP St. Paulus Ruteng. Magister Scientiae, (38), 93-107. Retrieved from http://journal.wima.ac.id/index.php/Magister_Scientiae/article/view/786

Halliday, M. A. K. An Introduction to Functional Grammar. Edited by Christian M. I. M. Matthiessen, 3rd ed., Routledge, 2014.

Halliday, M. A. K., \& Hasan, R. (1976). Cohesion in English. London, England: Longman.

Heino, P. (2010). Adverbial connectors in advanced EFL learners' and native speakers' student writing (unpublished Bachelor's thesis). Retrieved from http://www.divaportal.org/smash/get/diva2:325443/FULLTEXT01.pdf

Moleong, L. J. (2005). Metodologi penelitian kualitatif $\left(21^{\text {st }}\right.$ ed.). Bandung, Indonesia: Remaja Rosdakarya.

Nugraheni, R. (2015). Cohesive devices in learners' writing. LLT Journal: A Journal on Language and Language Teaching, 18(1), 51-61. doi:https://doi.org/10.24071/1lt.2015.180106

Ong, J. (2011). Investigating the use of cohesive devices by Chinese EFL learners. The Asian EFL Journal Quarterly, 13(3), 42-65. Retrieved from https://www.asian-efljournal.com/main-journals/investigating-the-use-of-cohesive-devices-by-chinese-efllearners/

Rezaee, A. A., and Nurrouzi, M. H. (2011). Readability formulas and cohesive markers in reading comprehension. Theory and Practice in Language Studies, 1(8), 1005-1010. doi:10.4304/tpls.1.8.1005-1010

Suningsih, S. (2016) The use of cohesive devices in students' writing (Tesis, Universitas Negeri Lampung, 2016). Retrieved from https://s3.amazonaws.com/academia.edu.documents/51422213/THESIS_WITHOUT_ RESULT_AND_DISCUSSION.pdf?re

Tirtasari, Iin. (2015) Cohesive devices used by the third semester students of English Department (Skripsi, Universitas Negeri Jambi, 2015). Retrieved from http://repository.fkip.unja.ac.id/file?i=uOMbSWJ2FxnaOn1L2GXNskEzU3oNQBD3DBZ5da3Tqw

Windyastuti, Prima. (2014). The use of cohesive devices in the English essays of semester IV students of Yogyakarta State University in the academic year of 2012/2013 (Skripsi, Univeristas Negeri Yogyakarta, 2014). Retrieved from http://eprints.uny.ac.id/id/eprint/18517

Zemach, D. E., \& Rumisek, L. A. (2005). Academic writing: From paragraph to essay. London, England: Macmillan 